\title{
School Leadership Strategies in the Digital Era
}

\author{
Tota Maria Nababan ${ }^{1, *}$ Zainuddin $^{2}$ Saut Purba ${ }^{3}$ Johannes Sohirimon Lumban Batu ${ }^{4}$ \\ Godlif Sianipar $^{5}$
}

\author{
${ }^{1}$ Postgraduate School in Education Management Program Universitas Negeri Medan North Sumatra, Indonesia \\ ${ }^{2,3}$ Postgraduate School Universitas Negeri Medan North Sumatra, Indonesia \\ ${ }^{4}$ STP St. Bonaventura Keuskupan Agung Medan North Sumatra, Indonesia \\ ${ }^{5}$ St. Thomas Catholic University Medan North Sumatra, Indonesia \\ *Corresponding author. Email: totamarianababan@gmail.com
}

\begin{abstract}
Leadership is one of the most important components in running an organization. Along with the rapid development of technology, leaders must have a strategy in carrying out their organization in order to achieve the expected goals, especially in the era of the industrial revolution 4.0. How the strategy that need will determine the fate of the school he leads. This study aims to determine how the principal's strategy in the digital era 4.0. This study used a qualitative approach and then it described in a narrative manner through critical analysis. The research respondents consisted of several teachers and school principals. The results showed that the principal's strategy to improve the quality of human resources was to increase the information. Communication technology knowledge of teachers and all human resources in schools; be a role model for his subordinates to be able to use technology in supporting work; adopt new useful information to be implemented; dissemination of important information on the benefits of technology to the guardians of students; work in a process and results oriented manner; master the $4 \mathrm{C}$ formula.
\end{abstract}

Keywords: strategy, leadership, technology, communication.

\section{INTRODUCTION}

The fourth world industrial revolution marked by information technology has become the basis of human life. Everything becomes limitless with the use of unlimited computing power and data, because it is influenced by the massive development of the internet and digital technology as the backbone of the movement and connectivity of humans and machines. This era will also disrupt various human activities, including the fields of science and technology and education.

All stakeholders in the education environment must respond the challenges of the industrial revolution 4.0 quickly and accurately in order to be able to increase the competitiveness of the Indonesian nation in the midst of global competition. "Strategic policies need to be formulated in various aspects ranging from institutions, fields of study, curriculum, resources, as well as the development of technology centre software tools, research and development to innovation".

Improving the quality of schools to be better than the previous performance is a very difficult thing and has long been a research interest at the international level. The challenge of school leaders in improving the quality of student learning outcomes will always be an interesting focus of educational research. Recently, the report of Organization for Economic Co-operation and Development (OECD) that $15 \%$ of low learning achievement was more likely to come from variations in socio-economic conditions, demographics and educational background of students [1]. At the same time, the challenges of learning achievement in the $21 \mathrm{st}$ century provide unique opportunities that have never existed before, namely the advantages of communication and information technology.

This phenomenon explains the development of leadership paradigm changes, especially in the context of educational leadership, as well as the actual conditions in which the digital world is so dominant and the opportunity to take advantage of it.

The picture above shows how the conditions of education are good and there is a very surprising hope in the world of education. in Japan, that an educator gives good questions to his students. What are the aspirations 
of the students? Immediately with enthusiasm the students responded wanting to become a teacher.

The problem lies in educational institutions in Indonesia, from primary to secondary schools, policies that are still unable to respond quickly when there is an opportunity to improve the teaching profession to keep up with educational developments in the digital era. This one thing is often blocked by policies in the school environment, resulting in a build-up of functional position groups.

So anything that wants to carry out the policies that have been programmed by the Ministry of Research, Technology and Higher Education regarding the need for changes in the digital era in all educational institutions must be gradual, for those who are able to carry out the needs of the digital era can be carried out and for those who are not able to be assisted with existing provisions in the government through agencies related to education.

The era of the Industrial Revolution 4.0 was marked by artificial intelligence, super computers, genetic engineering, Nanotechnology, automatic cars, and innovation. These changes occur at an exponential rate that will have an impact on the economy, industry, government, and politics. In this era, it is increasingly visible that the world has become a global village [2]. The Industrial Revolution 4.0 is a term that was first coined in Germany in 2011 which was marked by the digital revolution. This industry is a digitally connected industrial process that includes various types of technology, from 3D printing to robotics which is believed to be able to increase productivity. Before this there had been three industrial revolutions marked by the invention of the steam engine and the railroad in 17501930 , the invention of electricity, communication tools, chemistry, and oil in 1870-1900, and the invention of computers, the internet, and mobile phones in 1960 until now [2]. The challenges of the industrial revolution 4.0 must be responded to quickly and accurately by all stakeholders in order to be able to increase the competitiveness of the Indonesian nation in the midst of competition. Based on [3] notes that capital needed to enter the 21 st century and the 4.0 industrial revolution are:

- $\quad$ Students have critical thinking skills;

- Students have creativity and have innovative abilities;

- Students have the ability and communication skills;

- $\quad$ Students have the ability to work together and collaborate; and

- $\quad$ Students have self-confidence
Leadership in organizations has a very large role in building relationships between individuals and forming organizational values that used as the foundation for achieving organizational goals. The influence of leadership on organizational effectiveness seen as a direct and indirect leadership effect [4]. The principal in a school interpreted as the leader of the school or institution where he receives and gives lessons. The principal is a teacher who has the ability to lead all existing resources in a school so that they utilized optimally to achieve common goals [5]. Furthermore, according to the author [6], principals who are experienced in carrying out their main tasks, the easier it is to provide speed, convenience, accuracy and integration in providing performance services. The more work experience a person has, the more benefits that will have an impact on the breadth of knowledge in the field of work and the increasing skills of a person [4].

\section{THEORETICAL DESCRIPTION}

\subsection{Industrial Revolution 4,0}

Next, the [7] revealed that Industry 4.0 is the integration of Cyber Physical System (CPS) and Internet of Things and Services into industrial processes including manufacturing and logistics and other processes. CPS is a technology to combine the real world with the virtual world. The term Industry 4.0 was born from the idea of the fourth industrial revolution. According to author [6] that the Year 2011 marked the first official use of the term Industry 4.0. Publicity and demonstrations of how it could benefit the company began to appear in the presentations. In 2013, the German manufacturing industry chose to invest in the Industry 4.0 process and the German government increased funding, which led to the creation of the Industry 4.0 Platform. In 2014, digital product manufacturing activities and the utilization of Learning of Things began to occur.

The author [8] mentioned that workers in all fields in the era of the Industrial Revolution 4.0 are required to have digital skills, both technical and managerial workers. In addition to the demands for appropriate skills, it turns out that social skills are also indispensable in working in the era of the Industrial Revolution 4.0. The results of studies in several developed countries show that there is an increasing need for analytical non-routine skills and interactive non-routine skills. Meanwhile, the need for cognitive routine skills, manual non-routines, and manual routines has decreased.

\subsection{Leadership and Principal}

Leadership is a translation of the word "leadership" which comes from the word "leader". A leader is a person who leads. While leadership is his position. In another sense, etymologically the term leadership comes from the basic word "pimpin" which means to guide or guide. 
From "pimpin" was born the verb "leader" which means to guide and demand. The same way, the author [9] states that leadership is about direction setting and inspiring others to make the journey to a new and improved state of school. Leadership is about managing leadership and inspiring others to do something new and improve the school organization.

According to [10], leadership is the behaviour of a leader to direct, influence, and explain to subordinates, initiate and maintain group cohesiveness, consistent attitude so that each member can contribute effectively to the organization in order to achieve goals. Meanwhile, [6] concluded that leadership in the field of education also has the understanding that leaders must have skills in influencing, encouraging, guiding, directing, and mobilizing others who have to do with the implementation and development of education and teaching or training so that all activities can run effectively and efficiently which in turn will achieve the educational and teaching goals that have been set.

The expected leadership is future-oriented leadership (transformation leadership) [11]. The principal comes from two words principal and school. The head can be interpreted as chairman or leader. While the school is defined as an institution in which there are teaching and learning activities. School is also a living environment after home, where children live a few hours where children are generally in the developmental period, and educational institutions and places that function to prepare children to face life [3]. While the principal can be defined as a functional teacher who is given the task of leading a school where the teaching and learning process is held or a place where there is interaction between teachers who give lessons and students who receive lessons [5].

\section{METHOD}

The research method used is a literature study, namely a review study of journals, articles, books and writings related to leadership in educational institutions. The research stages start from: determining the research topic, then conducting a study with theories that are relevant to the research topic. Data collection consists of three main processes, namely: editing (checking data), organizing (organize the data obtained with the framework that is already needed), and finding (analysing data). To obtain correct and precise results in analysing the data, the author uses content analysis techniques.

\section{RESULT AND DISCUSSION}

The principal is a professional or teacher who is given the task of leading a school where the school becomes a place of interaction between teachers who give lessons, students who receive lessons, parents as expectations, graduate users as recipients of satisfaction and the general public as pride. This is relevant with [6] statement that principals are successful if they understand the existence of the school as a complex and unique organization, and are able to carry out the role of the principal as someone who given the responsibility to lead the school. Principal success studies show that the principal is someone who determines the centre point and rhythm of a school. Even further the study concluded that "school success is the success of the principal" some of the principals are described as people who have high expectations for staff and students, principals are those who know a lot about their duties and those who set the rhythm for their school.

Based on the formulation of the results of the study above, it shows how important the role of school principals is in moving school life to achieve goals. There are two things that need to be considered in the formulation, namely as follows: 1) The principal acts as a central force that is the driving force of school life; and 2) Principals must understand their duties and functions for the success of the school, and have concern for staff and students [4].

The digital era, which is marked by the role of information and communication technology, demands the role of school principals in the Industrial Era 4.0 to form students who have 21 st century competencies to be able to think critically, creatively, collaboratively, and communicatively. Quality students are the output of a good school system.

The principal is the main actor who manages inputs, processes, and outputs based on the National Education Standards (SNP). Therefore, 21st century leadership for school principals can be done with several strategies.

1) Visionaries. The principal must be able to see the opportunities and potentials that exist by identifying problems in his school as the basis for school development. The most important thing for school principals is the active involvement of school stakeholders, namely, teachers, education staff, students and parents as well as related parties outside the school to solve school problems.

2) Designer. The principal in his role as a supervisor must be able to act as an instructional leader in designing and implementing 21 st century learning according to the concept of a higher order thinking skills approach or HOTS.

3) Influencer. School principals as 21 st century education leaders must be able to invite all educational stakeholders in schools, both teachers, education staff and parents of students to jointly create dynamic education in accordance with the development of industry 4.0 .

4) Motivator. The principal must provide enthusiastic support and appreciation to teachers, 
education staff and students who have achieved results for achievements, innovations and other achievements that are proud.

5) Trendsetter. The principal must be able to be a role model for his subordinates as shown by the ability to use new technology.

The industrial developments that lead to digitalization or known as industry 4.0 directly enter the realm of education, especially schools. There are various kinds of technology initiatives, where from the platform side, principals and teachers can use a curriculum based on the competency level of their students to carry out various kinds of platform infrastructure which can later be used for the education system to improve competence, efficiency, as well as personalization or accuracy of student competencies.

The demand for the capacity of school principals for various technology platforms embedded in schools is of course balanced with the government's efforts towards the school digitization program which has been launched since 2020 through the launch of an independent learning program and an independent campus. The program is marked by the implementation of Distance Learning or School Digitization.

\section{CONCLUSION}

From the results and discussion, it can be seen that the ideal leadership in the digital era is leadership that follows the industrial revolution 4.0. Leaders who follow the development of technology leaders must have skills in, encourage, direct, and mobilize others that have to do with the implementation and development of education and teaching in the digital era. The school leadership strategy in the digital era is that besides being a leader who is able to use technology, he must also be a visionary, designer, influencer, supporter, and trendsetter for the people around him.

\section{ACKNOWLEDGMENT}

Thank you to the lecturers at the State Universitas Negeri Medan, especially the Education Management Study Program in the Postgraduate class for giving knowledge to the author. To my promoters, Prof. Dr. Zainuddin and Dr. Saut Purba. Thank you to the entire AISTEEL 2021 committee for the publication of this article/proceeding

\section{REFERENCES}

[1] OECD (2018). Programme for International Student Assessment (PISA) 2018 Database. https://www.oecd.org/pisa/publications/PISA2018 CN_IDN.pdf

[2] Herawaty Adya, et al (2021). Industrial revolution 4.0: What should be prepared for the next stage? Jurnal Inovasi Ekonomi, Vol 6(1).
[3] Sihotang, D. O. (2019). Optimalisasi Penggunaan Google Class Room Dalam Peningkatan Minat Belajar Bahasa Inggris Siswa Di Era Revolusi Industri 4.0 (Studi Kasus di SMK Swasta Arina Sidikalang). Jurnal Teknologi Kesehatan Dan Ilmu Sosial (Tekesnos), 1(1), 77-81. Retrieved from http://e-journal.sari-

mutiara.ac.id/index.php/tekesnos/article/view/981

[4] Handoyo, dkk (2015). The Influence of leadership Style on Employee's Performance through Work Motivation (An Organizational Study at Four Hotels in Malang). Jurnal Administrasi Bisnis (JAB), Vol 22(1)

[5] H. Timperley, A. Wilson, H. Barrar \& I. Fung (2007). Teacher Professional Learning and Development: Best Evidence Synthesis Iteration Wellington, New Zealand: Ministry of Education http://educationcounts.edcentre.govt.nz/goto/BES

[6] J. Rajagukguk, et al (2020). A superior Leadership style in Schools (Case study at SMA Negeri 1 Medan). Proceedings of the 5th Annual International Seminar on Transformative Education and Educational Leadership (AISTEEL 2020). https://doi.org/10.2991/assehr.k.201124.058

[7] Alsalman, Huhsam \& Salih, Muataz. (2019). A review Cyber of Industry 4.0 (Cyber-Physical Systems (CPS), the Internet of Things (IoT) and the Internet of Services (IoS)): Components, and Security Challenges. Journal of Physics: Conference Series. $\quad 1424.012029 .10 .1088 / 1742$ 6596/1424/1/012029.

[8] M. Sagita, Khairunnisa (2020). E-Learning for Educators in Digital Era 4.0. Budapest International Research and Critics Institute-Journal (BIRCIJournal), Vol 3(2), 1297-1302. DOI: https://doi.org/10.33258/birci.v3i2.974

[9] Amriani Ade, et al (2020). Best Leadership Principals of Remote Elementary Schools in the Future. Proceedings of the 5th Annual International Seminar on Transformative Education and Educational Leadership (AISTEEL 2020). https://doi.org/10.2991/assehr.k.201124.052

[10] Siahaan M. Tumpal, et al (2020). Principals School Commitment in the Implementation, and Supervision Quality of Education in the Future, Proceedings of the 5th Annual International Seminar on Transformative Education and Educational Leadership (AISTEEL 2020). https://doi.org/10.2991/assehr.k.201124.062

[11] L. Yin Fong, et al (2020). Transformational Leadership and Job Performance: The Mediating Role of Work Engagement. SAGE Open, Vol 1(11). DOI: $10.1177 / 2158244019899085$ 